\title{
PENGARUH CORPORATE GOVERNANCE DAN RASIO AKUNTANSI TERHADAP PERINGKAT OBLIGASI
}

\author{
Eka Wahyu Damayanti \\ Fitriyah \\ Fakultas Ekonomi Universitas Islam Negeri Maulana Malik Ibrahim Malang \\ Jalan Gajayana 50 Malang \\ Email: fitriyah_feuin@yahoo.com
}

\begin{abstract}
This research was aimed to examine the effect of good corporate governance and the accounting ratios that partially or simultaneously are concerned with bond credit ratings. The population in this research are are all the companies rated by PT.PEFINDO over the period 2010 to 2011. Sampling using a purposive sampling technique and number of sample are 42 companies. The analysis method of logistic regression is used for measuring the effect of good corporate governance, the financial ratios and bond credit ratings. The result shows, the value of the Adjusted R Square of 0,45 or $45 \%$ indicates that the independent variable, namely corporate governance and accounting ratios, can explain the dependent variable bond ratings by $45 \%$ while the remaining $55 \%$ is explained by other factors outside the model studied. Significant variable are the board, audit committe, the company's growth in the proxy by ROA, Leverage ratio in proxy by DER, Slovency ratio and Liquidity ratio. This situation is based upon the significant number of 0,05 , while the variables that are not significant are the NPM variables, Sales to Asset, Institutional ownership, managerial ownership and the size of the board of commissioners.
\end{abstract}

Keyword: corporate governance, rasio akuntansi, peringkat obligasi

Seiring perkembangan dan pertumbuhan ekonomi, pasar modal memiliki peran penting dalam meningkatkan pertumbuhan perekonomian. Dalam melaksanakan fungsi ekonomi, pasar modal menyediakan fasilitas untuk memindahkan dana dari pihak yang memiliki dana lebih kepada pihak yang membutuhkan dana untuk dikelola sehingga mendapatkan keuntungan. Sementara dalam melaksanakan fungsi keuangan, pasar modal menyediakan dana yang dibutuhkan oleh pihak yang memerlukan dana, dan pihak yang memiliki kelebihan dana dapat ikut terlibat dalam kepemilikan perusahaan 
tanpa harus menyediakan aktiva riil yang diperlukan untuk melakukan investasi (Bachri dalam Sutedi, 2011:15).

Keberadaan pasar modal merupakan wadah yang dapat digunakan untuk para investor dan perusahaan. Berbagai instrumen keuangan dapat digunakan sebagai pilihan untuk menginvestasikan dana. Investasi pada pasar modal dibagi menjadi dua jenis yaitu Investasi dalam surat kepemilikan (saham) dan investasi dalam surat hutang (obligasi). Banyak investor lebih tertarik menanamkan modalnya pada obligasi hal ini dikarenakan volalitas obligasi dibandingkan dengan saham lebih rendah. Faerber (2000) dalam Setyapurnama (2006:2) menyatakan bahwa investor lebih memilih berinvestasi pada obligasi dibanding saham karena dua alasan, yaitu: (1) volatilitas saham lebih tinggi dibanding obligasi, sehingga mengurangi daya tarik investasi pada saham, dan (2) obligasi menawarkan tingkat pengembalian yang positif dengan pendapatan tetap (fixed income), sehingga obligasi lebih memberikan jaminan dibanding saham. Obligasi memiliki tingkat fluktuasi performa yang rendah serta lebih memberikan jaminan pengembalian dan keuntungan dibanding investasi saham.

Hal lain yang menarik investor lebih memilih obligasi adalah resiko perusahaan tidak mampu memenuhi kewajibannya membayar bunga dan pokok pinjaman. Ketidakmampuan ini dipengaruhi oleh kinerja perusahaan penerbit obligasi. Untuk mengkonpensasikan investor obligasi atas resiko gagal bayar, obligasi harus memberikan premi gagal bayar, yaitu selisih dari tingkat keuntungan yang dijanjikan atas tingkat keuntungan yang diberikan oleh sekuritas pemerintah yang bebas resiko gagal bayar (Rodoni, 2008:55, dalam Nasarud 2010:19).

Informasi tentang peningkatan obligasi dijelaskan oleh Hoesen (www.detikfinance) dimana banyaknya perusahaan yang menerbitkan obligasi didasari oleh investasi Indonesia yang tergolong baik. Obligasi jauh lebih menguntungkan dibandingkan pinjaman perbankan dengan penawaran bunga yang lebih rendah. Hal ini tentunya merupakan informasi yang cukup penting bagi para investor. Seseorang yang ingin berinvestasi obligasi tentunya harus mengetahui informasi yang akan dijadikan landasan pengambilan keputusan. 
Peringkat obligasi merupakan salah satu informasi yang digunakan sebagai dasar pengambilan investasi obligasi tersebut.

Peringkat obligasi ini mengukur adanya resiko gagal bayar berupa ketidakmampuan emiten sebagai penghutang dalam membayar bunga selama umur obligasi dan pelunasannya pada jatuh tempo. Jewell dan Livingston (2000:6) menyimpulkan bahwa adanya informasi yang berbeda merupakan masalah yang menimbulkan adanya beragam karakteristik dari pihak penerbit obligasi. Peringkat obligasi yang diumumkan ke publik dapat mengurangi asimetri informasi perusahaan penerbit obligasi dan investor (Zuhrohtun dan Baridwan,2005:355).

Peringkat obligasi mempunyai arti penting bagi perusahaan ataupun investor. Banyak obligasi dapat dibeli oleh institusi bukan individual yang dilihat dari peringkatnya, artinya jika obligasi sebuah perusahaan turun berada pada peringkat $\mathrm{B}$ atau obligasi berperingkat rendah, maka perusahaan tersebut akan kesulitan dalam menjual obligasinya. Hal ini dikarenakan perusahaan sulit mengeluarkan obligasi baru karena pasar akan berpindah kepada perusahaan yang mempunyai peringkat lebih baik (Brigham, 2003:375).

Terdapat dua faktor yang mempengaruhi peringkat obligasi yaitu faktor keuangan dan faktor non keuangan. Faktor keuangan yaitu dilihat dari rasio profitabilitas, rasio leverage, rasio solvabilitas dan rasio likuiditas. Semakin baik rasionya semakin tinggi peringkatnya. Faktor non keuangan yaitu, faktor lingkungan hidup, provisi penjamin, stabilitas, regulasi dan lain sebagainya (Brigham ,2003:374).

Faktor penentu utama dari peringkat utang atau obligasi adalah kondisi keuangan perusahaan, namun demikian praktek dari corporate governance juga dapat membantu menjelaskan perbedaan peringkat utang antar perusahaan yang tidak tertangkap di kondisi keuangan masing-masing perusahaan. Untuk memonitor kinerja suatu perusahaan dapat dilihat dari adanya implementasi Good Corporate Governance (Tata Kelola Korporasi). Sistem corporate governance memberikan perlindungan efektif bagi pemegang saham dan kreditor sehingga mereka yakin akan memperoleh return atas investasinya dengan benar. Corporate 
governance juga membantu menciptakan lingkungan kondusif demi terciptanya pertumbuhan yang efisien dan sustainable di sektor korporat (Nasution dan Setiawan,2008:2). Di dalam mekanisme pasar juga mempunyai hubungan yang berkaitan dengan corporate governance. Keterbukaan, efisien pasar, loyalitas adalah beberapa implementasi good corporate governance yang akan berlangsung efektif.

Nasarud dalam Zarkasyi (2008:13) mengemukakan bahwa corporate governance yang tidak efektif merupakan penyebab utama terjadinya krisis ekonomi dan kegagalan berbagai perusahaan di indonesia. Corporate governance merupakan salah satu indikasi untuk penilaian tentang kinerja suatu perusahaan yang juga merupakan salah satu tolak ukur bagi para investor jika ingin melakukan investasi obligasi.

Penelitian Bhojraj dan Sengupta (2003) dalam Nasarud (2010:21) dikatakan bahwa corporate governance mempunyai hubungan positif dengan peringkat obligasi dan berhubungan negatif dengan yield obligasi. Adanya hubungan positif peringkat obligasi dengan implementasi good corporate governance merupakan salah satu informasi yang dapat digunakan bagi seorang investor dalam pengambilan keputusan apakah obligasi tersebut baik dijadikan investasi apa tidak. Mekanisme CG dapat mengurangi resiko gagal bayar (default risk) dengan cara mengurangi biaya agensi (agency cost) yaitu dengan memonitor kinerja manajemen dan mengurangi asimetri informasi antara perusahaan dengan kreditur. Mereka juga menemukan bahwa perusahaan dengan kepemilikan institusional dan komposisi komisaris independen yang besar memiliki peringkat surat utang yang tinggi dan bond yield yang rendah.

Penelitian Amrullah (2007:65) menemukan lima rasio keuangan yaitu leverage, likuiditas, solvabilitas, profitabilitas,dan produktivitas mampu membedakan peringkat obligasi yang termasuk investmen grade dan noninvestmen grade: rasio keuangan dapat membentuk model dan dapat digunakan untuk memprediksi peringkat obligasi pada perusahaan industri. Pada Penelitian Manurung et all (2007:11) menyimpulkan bahwa Beta, Net Profit Margin (NPM), Return On Equity (ROE) dan Debt to Equity Ratio (DER) tidak berpengaruh 
terhadap rating obligasi yang dikeluarkan oleh lembaga pemeringkat. Sedangkan pada current ratio (CR), total asset turnover (TAT), dan return on asset (ROA) berpengaruh signifikan terhadap rating obligasi yang dikeluarkan oleh PEFINDO.

Penelitian Prasetiyo (2010:98) menyimpulkan kepemilikan institusi, kepemilikan manajerial, proporsi dewan komisaris tidak berpengaruh secara signifikan terhaap peringkat obligasi; dewan komisaris, komite audit, dan ROA berpengaruh positif terhadap peringkat obligasi. Dengan adanya implementasi corporate governance hal itu akan berdampak pada kinerja suatu perusahaan yang dapat dilihat dari peringkat obligasi dan rasio akuntansi. Sehingga tujuan penelitian ini adalah untuk mengetahui apakah ada pengaruh secara simultan dan partial penerapan Good Corporate Governance dan rasio akuntansi terhadap peringkat obligasi.

\section{Corporate Governance}

Tata kelola perusahaan yang baik (good corporate governance) merupakan struktur yang oleh stakeholder, pemegang saham, komisaris dan manajer menyusun tujuan perusahaan dan sarana untuk mencapai tujuan tersebut dan mengawasi kinerja (OECD, 2003 dalam Zarkasyi, 2008:35). Forum for Corporate Governance in Indonesia (FCGI) mendefinisikan corporate governance sebagai seperangkat peraturan yang menetapkan hubungan antara pemegang saham, pengurus, pihak kreditor, pemerintah, karyawan dan para pemegang kepentingan intern dan ekstern lainnya sehubungan dengan hak-hak dan kewajiban mereka.

Pelaksanaan good corporate governance diharapkan dapat memberikan beberapa manfaat berikut ini (FCGI, 2001); (1) Meningkatkan kinerja perusahaan melalui terciptanya proses pengambilan keputusan yang lebih baik, meningkatkan efisiensi operasional perusahaan serta lebih meningkatkan pelayanan kepada stakeholders. (2) Mempermudah diperolehnya dana pembiayaan yang lebih murah sehingga dapat lebih meningkatkan corporate value. (3) Mengembalikan kepercayaan investor untuk menanamkan modalnya di 
Indonesia. Pemegang saham akan merasa puas dengan kinerja perusahaan karena sekaligus akan meningkatkan shareholders value dan dividen.

Pelaksanaan good corporate governance dilakukan dengan menggunakan prinsip-prinsip yang berlaku secara internasional, yaitu (FCGI, 2001); (1) Hakhak para pemegang saham. (2) Perlakuan sama terhadap pemegang saham. (3) Peranan pemegang saham harus diakui. (4) Pengungkapan yang akurat dan tepat pada waktunya serta transparasi mengenai semua hal yang penting bagi kinerja perusahaan, kepemilikan, serta para pemegang kepentingan (stakeholders). (5) Tanggungjawab pengurus dalam manajemen, pengawasan manajemen serta pertanggungjawaban kepada perusahaan dan para pemegang saham.

Mekanisme corporate governance secara keseluruhan terdiri dari pertama, dewan direksi merupakan organ perusahaan yang memiliki fungsi utama memberi perhatian secara bertanggung jawab (oversight function) terhadap penerapan GCG dalam rangka mencapai tujuan perusahaan (Warsono,dkk, 2010: 55). Dewan direksi bertanggung jawab atas beberapa fungsi manajemen tanpa harus terlibat secara langsung dalam kegiatan operasionalnya. Fungsi utama adanya dewan direksi adalah menetapkan tujuan strategi dan prinsip-prinsip yang akan dijadikan sebagai acuan operasional (Ahmed,2008:42).

Kedua komisaris independen adalah organ peseroan yang bertugas melakukan pengawasan secara umum dan/atau khusus sesuai dengan anggaran dasar serta memberi nasihat kepada direksi (Zarkasyi,2008:76). Komisaris Independen mempunyai tugas dan wewenang di dalam pelaksanaan corporate governance, pada tanggal 1 Juli 2000 BEI mengatur tentang keberadaan komisaris independen. FCGI menetapkan bahwa jumlah minimal komisaris independen adalah 30\% dari seluruh anggota komisaris independen. Fungsi dari komisaris independen adalah memonitor kinerja dari dewan direksi.

Ketiga komite audit bertugas memberikan suatu pandangan tentang masalah akuntansi, laporan keuangan dan penjelasannya, sistem pengawasan internal serta auditor independen (Zehnder, 2000 dalam Warsono, 2009:87). Adanya komite audit bertujuan untuk memberikan pandangan dan pengarahan dalam masalah-masalah yang ada hubungannya dengan akuntansi,kebijakan 
keuangan, transparasi. Komite audit merujuk kepada tanggung jawab penerapan good corporate governance yang dimana di dalam implementasi tersebut adanya jaminan kualitas, integritas, transparasi, dan fungsi kualitas audit.

Keempat kepemilikan institusional merupakan salah satu alat yang dapat digunakan untuk mengurangi agency conflict. Dengan kata lain semakin tinggi tingkat kepemilikan institusional, semakin kuat tingkat pengendalian yang dilakukan oleh pihak eksternal terhadap perusahaan, sehingga agency cost yang terjadi di dalam perusahaan semakin berkurang dan nilai perusahaan juga semakin meningkat (Jensen dan Meckling (1976) dalam Prasetiyo (2010:42).

Kelima, kepemilikan manajerial merupakan konsentrasi kepemilikan saham yang dimiliki oleh pihak manajemen di dalam suatu perusahaan. Adanya kepemilikan manajerial biasanya akan menimbulkan masalah diantara pengelola dengan perusahaan yang mempunyai tujuan masing-masing. Model manajerial ditandai dengan terpisahnya pengelolaan perusahaan dari kepemilikan (Prasetyantoko,2008:59).

\section{Peringkat Obligasi}

Menurut Brigham (2010:300) Peringkat obligasi disarakan atas faktorfaktor kualitatif dan kuantitatif rasio keuangan, ketentuan hipotik, ketentuan subordinasi, ketentuan, dana, jatuh tempo, stabilitas, regulasi, antitrust, faktor lingkungan, kewajiban atas produk, kewajiban pensiun, masalah ketenagakerjaan, dan kebijakan akuntansi. Peringkat obligasi menunjukan kualitas kredit perusahaan penerbit. Semakin dekat peringkat obligasi dengan idAAA berarti semakin bagus peringkatnya dan semakin kecil kemungkinan obligasi akan gagal dalam memenuhi kewajiban membayar bunga dan pokok pinjamannya (Tandelilin: 2010:251). Peringkat ini dimulai dari idAAA sampai yang terendah idD.

\section{Rasio Keuangan}

Rasio keuangan adalah salah satu sumber informasi yang dapat digunakan untuk memperoleh gambaran kondisi keuangan suatu perusahaan. Analisis Laporan Keuangan merupakan alat analisis bagi manajemen keuangan 
perusahaan yang bersifat menyeluruh, dapat digunakan untuk mendeteksi atau mendiagnosis tingkat kesehatan perusahaan yang bersifat parsial maupun kinerja organisasi (Harmono, 2011:104).

Rasio keuangan terdiri dari rasio likuiditas, leverage, solvabilitas, profitabilitas dan produktifitas. Rasio likuiditas adalah rasio yang menggambarkan kemampuan perusahaan dalam memenuhi kewajiban jangka pendek (Kasmir, 2008:128). Rasio leverage merupakan rasio keuangan yang menunjukkan proporsi penggunaan utang untuk membiayai investasi terhadap modal yang dimiliki. Rasio ini digunakan untuk mengukur sejauh mana suatu perusahaan menggunakan utang dalam membiayai investasinya. Rasio ini digunakan untuk mengukur keseimbangan proporsi antara aktiva yang didanai oleh kreditor (utang) dan yang didanai oleh pemilik perusahaan (ekuitas) (Linandarini, 2010:48).

Rasio solvabilitas suatu perusahaan menunjukkan kemampuan perusahaan untuk memenuhi segala kewajiban finansialnya pada saat perusahaan itu dilikuidasi. Rasio Profitabilitas merupakan rasio untuk menilai suatu perusahaan dalam mencari keuntungan, rasio ini menunjukan ukuran tingkat efektifitas manajemne suatu perusahaan (Kasmir,2008:196). Menurut Hardwick,dkk (1998) dalam Margaretha (2009:29) semakin tinggi tingkat profitabilitas perusahaan maka semakin rendah risiko ketidakmampuan membayar (Default) dan semakin baik peringkat yang diberikan terhadap perusahaan tersebut.

Rasio produktivitas ini mengukur seberapa efektif perusahaan mempergunakan sumber daya yang dimiliki perusahaan tersebut. Perusahaan yang tingkat produktivitasnya tinggi cenderung lebih mampu menghasilkan laba yang lebih tinggi dibandingkan dengan perusahaan yang tingkat produktivitasnya rendah (Amrullah, 2007:39). Rasio ini secara signifikan berpengaruh positif terhadap peringkat obligasi. Menurut Horrigen (1966) dalam Margaretha (2009:29) rasio produktivitas secara siginifikan berpengaruh positif terhadap credit rating. Semakin tinggi rasio produktivitas maka semakin baik peringkat perusahaan tersebut. 


\section{METODE}

Lokasi penelitiani ini adalah pada perusahaan yang mempunyai peringkat obligasi yang di rating oleh PT.PEFINDO periode 2010-2011 yang memiliki laporan GCG dan laporan keuangan. Adapun data diambil melalui situs PEFINDO dan website masing-masing perusahaan yang masuk di dalam sampel penelitian.

Populasi dalam penelitian ini adalah perusahaan yang tergabung dalam peringkat obligasi yang dirating oleh PT.PEFINDO selama periode 2010 sampai 2011. Perusahaan yang termasuk dalam populasi yang digunakan dalam penelitian ini berjumlah 105 perusahaan. Sedangkan sampel dalam penelitian ini adalah perusahaan yang tergabung dalam peringkat obligasi yang dirating oleh PT.PEFINDO periode 2010 sampai 2011. Sampel diambil dengan menggunakan teknik purposive sampling dimana perusahaan yang menjadi sampel dipilihkan berdasarkan kriteria-kriteria tertentu.

Adapun kriteria yang ditetapkan peneliti dalam penelitian ini adalah 1) Telah terdaftar di Bursa Efek Indonesia (BEI) pada tahun 2010-2011; 2) Terdaftar dalam peringkat obligasi yang dirating oleh PT.Pefindo tahun 2010-2011; 3) Menerbitkan laporan GCG; 4) Mempunyai id atau rangking AAA - B; 5)Memiliki data mengenai dewan komisaris independen, kepemilikan institusional, komite audit, kepemilikan manajerial dan 6) Mempunyai laporan keuangan dan data yang lengkap untuk perhitungan rasio keuangan.

Dari kriteria yang telah ditentukan oleh peneliti, maka sampel penelitian ini ditetapkan sejumlah 42 perusahaan, seperti pada tabel berikut:

Tabel 1.Sampel perusahaan penerbit obligasi

\begin{tabular}{|c|c|l|}
\hline No & Sektor & \multicolumn{1}{c|}{ Perusahaan } \\
\hline 1 & Automotive, Related & Selamat Sempurna \\
& Industry & Serasi Auto Raya \\
& & Sarana Multi Griya \\
\hline 2 & Finance Company & Adira Dinamika Multi Finance \\
& & Astra Sedaya Finance \\
& & BFI Finance Indonesia Tbk \\
& & Clipan Finance Indonesia Tbk \\
& & Federal International Finance \\
& & Indomobil Finance Indonesia \\
\hline
\end{tabular}




\begin{tabular}{|c|c|c|}
\hline & & $\begin{array}{l}\text { Oto Multiartha } \\
\text { Sarana Multigriya Financial (Persero) } \\
\text { Summit Oto Finance } \\
\text { Surya artha Nusantara Finance } \\
\text { Mandiri Tunas Finance } \\
\text { Toyota Astra Finance Services } \\
\text { Wahana Oto Multiartha (WOM) }\end{array}$ \\
\hline 3 & Retail & $\begin{array}{l}\text { Matahari Putra Prima Tbk } \\
\text { Mitra Adiperkasa Tbk }\end{array}$ \\
\hline 4 & $\begin{array}{l}\text { Shipping Marine } \\
\text { Transport Service }\end{array}$ & $\begin{array}{l}\text { Berlian Laju Tanker Tbk } \\
\text { Arpeni Putra Pratama Tbk }\end{array}$ \\
\hline 5 & Wood Based and Agro & $\begin{array}{l}\text { BW Plantantion Tbk } \\
\text { PTPN } 7 \\
\text { JAPFA }\end{array}$ \\
\hline 6 & Fertilizer & Pupuk Kalimantan Timur \\
\hline 7 & Chemical & Lautan Luas Tbk \\
\hline 8 & Consumer Goods & $\begin{array}{l}\text { Indofood Sukses Makmur Tbk } \\
\text { Mayora Indah Tbk } \\
\text { PT.Salim Ivomas Pratama }\end{array}$ \\
\hline 9 & Infrastructure & $\begin{array}{l}\text { Jasa Marga (Persero) } \\
\text { PLN (Persero) }\end{array}$ \\
\hline 10 & Mining, Oil, and Natural & $\begin{array}{l}\text { Apexindo Pratama Duta Tbk } \\
\text { Medco Energy International Tbk }\end{array}$ \\
\hline 11 & Poultry & $\begin{array}{l}\text { JAPFA comfeed Indonesia } \\
\text { Malindo Feedmill Tbk }\end{array}$ \\
\hline 12 & $\begin{array}{l}\text { Property and } \\
\text { Construction }\end{array}$ & $\begin{array}{l}\text { Agung Podomoro Land } \\
\text { Adhi Karya (Persero) Tbk } \\
\text { Summarecon Agung Tbk } \\
\text { Bakrieland Development Tbk }\end{array}$ \\
\hline 13 & Securities Company & $\begin{array}{l}\text { MNC securities } \\
\text { Danareksa (Persero) }\end{array}$ \\
\hline 14 & Telecommunication & $\begin{array}{l}\text { Indosat Tbk } \\
\text { PerusahaanPerseroan } \\
\text { (Persero)Telekomunikasi Indonesia }\end{array}$ \\
\hline
\end{tabular}

Sumber : data sekunder yang diolah

Teknik analisis data yang digunakan dalam penelitian ini menggunakan Regresi Logistik dan analisis regresi karena dalam penelitian ini terdapat lima variabel bebas untuk rasio keuangan dan enam variabel bebas untuk proxi corporate governance dan satu variabel terikat yaitu peringkat obligasi.

\section{HASIL}

\section{Analisis Regresi Logistik}


Tabel 2. Regression Logistic

\begin{tabular}{|l|l|l|l|l|l|l|l|l|}
\hline & & & & & & & \multicolumn{2}{|l|}{$\begin{array}{l}\text { 95,0\% C.I for EXP } \\
(\mathrm{B})\end{array}$} \\
\hline & $\mathrm{B}$ & S.E & $\begin{array}{l}\text { Wal } \\
\mathrm{d}\end{array}$ & $\begin{array}{l}\mathrm{d} \\
\mathrm{f}\end{array}$ & Sig. & Exp(B) & $\begin{array}{l}\text { Lowe } \\
\mathrm{r}\end{array}$ & Upper \\
\hline Roa & 5.522 & 1,890 & 8.536 & 1 & .003 & 250.111 & 6.157 & $1.016 \mathrm{E} 4$ \\
\hline Der & 1.638 & .715 & 5.254 & 1 & .022 & .194 & .048 & .789 \\
\hline CR & 2.265 & .957 & 5.595 & 1 & .018 & .104 & .016 & .678 \\
\hline ROE & .648 & 1.264 & .263 & 1 & 0.60 & 1.913 & .161 & 22.768 \\
\hline NPM & -.283 & .923 & .094 & 1 & .075 & .754 & .123 & 4.603 \\
\hline Sales & 1.058 & .941 & 1.264 & 1 & .261 & 2.881 & .455 & 8.227 \\
\hline Komisaris & 1.182 & 1.542 & .587 & 1 & .044 & 3.260 & .159 & 66.991 \\
\hline Kep.Inst & -.302 & .844 & .128 & 1 & .720 & .739 & .141 & 3.865 \\
\hline $\begin{array}{l}\text { Kep.Mana } \\
\text { je }\end{array}$ & 20.712 & 11.559 & 3.211 & 1 & .073 & $9.884 \mathrm{E} 8$ & .143 & $6.816 \mathrm{E} 18$ \\
\hline $\begin{array}{l}\text { Kom.audi } \\
\text { t }\end{array}$ & -.155 & 3.436 & .002 & 1 & .010 & .856 & .001 & 720.134 \\
\hline $\begin{array}{l}\text { Juml.kom } \\
\text { is }\end{array}$ & - & 24.651 & 1.944 & 1 & .163 & .000 & .000 & $1.137 \mathrm{E6}$ \\
\hline Constan & 1.228 & 1.357 & .819 & 1 & .365 & 3.415 & & \\
\hline
\end{tabular}

Sumber : data sekunder yang diolah

Berdasarkan tabel diatas di dapat persamaan logistik sebagai berikut :

$\mathrm{Y}=1,228-34,372$ KOMIN - 0,155AUDIT + 20,712MANAJERIAL 0,302INSTITUSI + 1,182KOMIS + 1,058SALES - 0,283NPM + 0,648ROE + 2,265CR $+1,638 \mathrm{DER}+5,522 \mathrm{ROA}$

Untuk melihat kecocokan model (model fit), kriteria yang digunkan adalah nilai -2Log Likehood (-2LL).

Tabel 3. Model Fit

\begin{tabular}{|ll|l|l|}
\hline Iteration & -2Log Likehood & Coefficient \\
\cline { 3 - 4 } & & constant \\
\hline Step 0 & 1 & 98.165 & .486 \\
& 2 & 98.163 & .496 \\
& 3 & 98.163 & .496 \\
\hline
\end{tabular}

Sumber : data sekunder yang diolah

Melihat model fit dapat dilihat dari statistik -2Log Likehood, yaitu tanpa konstanta sebesar 98,165 sedangkan setelah dimasukan variabel turun menjadi 98,163 . Hal ini dapat diartikan bahwa pertambahan variabel independen dapat memperbaiki model fit. Untuk melihat model fit yang lain dapat dilihat dengan nilai pada tabel Cox and Snell's R Square dan Negelkerke's R. 
Tabel 4

Model Summary

\begin{tabular}{|l|l|l|l|}
\hline Step & 2Log Likehood & $\begin{array}{c}\text { Cox and } \\
\text { Snell's R } \\
\text { Square }\end{array}$ & $\begin{array}{c}\text { Negelkerke's R } \\
\text { Square }\end{array}$ \\
\hline 1 & 71.687 & .301 & .459 \\
\hline & Chi-square & Df & Sig \\
\hline & 15.149 & 8 & .563 \\
\hline
\end{tabular}

Sumber : data sekunder yang diolah

Nilai Negelkerke's $\mathrm{r}$ Square diintepretasikan ssperti nilai $\mathrm{R}^{2}$ pada regreso linier. Hasil output SPSS memberikan nilai Cox and Snell's R Square sebesar 0,301 dan nilai Negelkerke's r Square sebesar 0,459. Hal ini menunjukan bahwa variabel independen yang dapat dijelaskan oleh variabilitas variabel dependen sebesar $45,9 \%$, sedangkan sisanya $54,1 \%$ dapat dijelaskan oleh variabel lainnya diluar variabel yang diteliti.

Model fit dapat juga dilihat dari uji Hosmer and Lemeshow's Goodness of fit, dimana jika nilai signifikansi dari Hosmer and Lemeshow's lebih dari 0,05 maka hipotesis nol diterima, yang berarti bahwa model tersebut dikatakn fit dan dapat diterima. Dengan menggunakan 11 variabel independen dalam model ini yaitu ROA, DER, CR, NPM, ROE, SALES to CA, kepemilikan manajerial ,kepemilikan institusi, komite audit, dewan komusaris dan jumlah komisaris independen menunjukan bahwa kebenaran prediksi model suatu perushaan dikategorikan dalam speculative grade sebesar $60,7 \%$ dan investment grade sebesar $87,7 \%$.

Kecilnya variabel peringkat obligasi yang dapat dijelaskan oleh variabel independen corporate governance dan rasio akuntansi dikarenakan adanya faktorfaktor lain yang mampu mempengaruhi peringkat obligasi tersebut. Faktor lain dapat dicontohkan seperti resiko industri, posisi pasar, arus kas, dan faktor lainnya (www.pefindo.com).

\section{PEMBAHASAN}

Pengaruh Kepemilikan Institusi terhadap Peringkat Obligasi 
Dari hasil analisis SPSS kepemilikan institusi yang dilihat dari kepemilikan saham mempunya nilai koefisien sebesar negatif 0,302 dengan tingkat signifikansi 0,720. Nilai signifikansi yang dihasilkan lebih besar dari 0,05 yang dapat disimpulkan bahwa H1 ditolak. Hasil penelitian ini tidak berhasil di dukung karena kepemilikan institusi mempunyai nilai signifikansi yang lebih besar dari 5\%. Hal ini berarti besar kecilnya proporsi saham yang ada pada perusahaan yang dimiliki oleh pihak institusi tidak berpengaruh terhadap peringkat obligasi.

Selain itu juga tanda koefisien yang dihasilkan juga negatif yang mengindikasikan bahwa tidak berpengaruh secara signifikan negatif. Hasil penelitian yang tidak signifikan menandakan bahwa adanya kepentingan dari pihak institusi dalam mengelola perusahaan. Atau dapat diartikan bahwa monitoring dalam suatu perusahaan tidak berjalan optimal (Prasetiyo,2010:89). Hal yang menyebabkan tidak signifikan mungkin dikarenakan jumlah pemilik institusi dibandingkan dengan pemilik manajerial jauh lebih besar, sehingga mengindikasikan sebagian besar saham terkonsentrasi pada mayoritas investor dan kemungkinan informasi akuntansi yang dihasilkan oleh manajemen dibuat berdasarkan kepentingan pemegang saham mayoritas.

Hasil penelitian ini berbanding terbalik dengan teori keagenan yang menyebutkan bahwa pemegang saham mayoritas akan berusaha meningkatkan nilai perusahaan yang pada akhirnya akan meningkatkan peringkat obligasi. Hasil penelitian ini konsisten dengan hasil penelitian Setyapurnama dan Norpratiwi (2006), Rinaningsih (2008) dimana variabel kepemilikan institusi tidak berpengaruh signifikan terhadap peringkat obligasi. Namun hasil penelitian ini tidak konsisten dengan hasil penelitian Setyaningrum (2005) dan Bhoraj dan Sengupta (2003) yang membuktikan bahwa peringkat obligasi mempunyai hubungan yang signifikan positid dengan persentase kepemilikan institusi.

\section{Pengaruh Kepemilikan Manajerial terhadap Peringkat Obligasi}

Hipotesis dua menyatakan bahwa kepemilikan manajerial berpengaruh negatif terhadap peringkat obligasi. Hasil SPSS menunjukan bahwa kepemilikan 
manajerial mempunyai nilai signifikansi 0,73 dan koefisien 20,712 dimana hasil ini menunjukan bahwa $\mathrm{H} 2$ diterima.

Variabel yang digunakan dalam kepemilkan manajerial adalah persentase jumlah saham yang dimiliki oleh pihak manajemen individu. Ausbaugh et.al (2004) dalam Setyaningrum (2005) mengungkapkan adanya kepemilikan manajerial menyebabkan peringkat obligasi menjadi rendah karena buruknya kualitas laba perusahaan.

Teori agensi memandang bahwa manajemen tiak dapat dipercaya mengelola kepentingan stakeholders. Hak pengendalian yang dimiliki manajer memungkinkan untuk diselewengkan dan akan menyebabkan masalah keagenan. Dan hal ini tentunya akan membuat peringkat obligasi menurun.

Hasil yang tidak signifikan ini kemungkinan disebabkan karena junlah persentase kepemilikan manajeria terlalu sedikit. Belum banyak perusahaan di Indonesia yang memiliki saham atau obligasi yang dikelola dengan jumlah yang signifikan.

\section{Pengaruh Ukuran Dewan Komisaris terhadap Peringkat Obligasi}

Dewan komisaris memegang peranana yang sangat penting di dalam perushaan. Hipotesis tiga menyatakan bahwa ukuran dewan komisaris berpengaruh positif terhadap peringkat obligasi. Hasil pengujian regresi logistic terhadap ukuran dewan komisaris mendapatkan nila signifikansi 0,044\% dan koefisien nilai positif sebesar 1,182. Nilai signifikansi tersebut lebih kecil daripada 0,05, seagkan tanda koefisien sesuai dengan tanda yang diajukan yaitu positif.

Hal ini berarti H3 diterima. Teori agensi menyatakan bahwa dewan komisaris adalah penanggung jawab yang mengawasi tindakan manajemen. Semakin banyak jumlah dewan komisaris maka semakin baik pengendalian yang ada pada perusahaan tersebut. Penelitian ini membuktikan bahwa ukuran dewan komiaris berpengaruh secara signifikan positif terhadap peringkat obligasi. Jadi semakin banyak atau semakin tinggi ukuran dewan komisaris maka akan berpengaruh pada peringkat obligasi, yaitu semakin baik peringkat obligasi. 
Hasil penelitian ini sesuai dengan penelitian yang dilakukan Kusumawati dan Riyanto (2005) yang menyatakan bahwa jumlah dewan komisaris berpengaruh positif terhadap kinerja perusahaan. Kinerja perusahaan yang baik akan berpnegaruh terhadap peringkat obligasi.

\section{Pengaruh Jumlah Komisaris Independen terhadap Peringkat Obligasi}

Sejumlah penelitian memberikan kesimpulan bahwa perusahaan yang mempunyai proporsi anggota dewan komisaris dari luar, maka akan mempengaruhi tindakan manajemen laba. Hipotesis empat menyatakan bahwa jumlah komisaris berpengaruh positif terhadap peringkat obligasi. Dari hasil penelitian ini diperoleh nilai signifikansi sebesar 0,163 dan tanda negatif -3.437. hal ini berarti hipotesis empat ditolak.

Jumlah proporsi komisaris independen menunjukan tidak berpengaruh signifikan terhadap peringkat obligasi. Kemungkinan hal ini dikarenakan ketentuan minimum 30\% belum cukup untuk memenuhi dewan komisaris independen dalam mengambil kebijakan. Hal ini berpengaruh pada kekuasaan dewan komisaris dalam memonitor. Jika mayoritas atau 50\% ukuran dewan komisaris dapat terpenuhi, maka bisa dikatakan monitoring yang ada pada perusahaan tersebut akan berjalan optimal karena kebijakan yang diambil dapat langsung berpengaruh terhadap peringkat obligasi perusahaan tersebut.

Hasil penelitian ini tidak konsisten dengan penelitian Setyaningrum dan Norpratiwi (2006), Asbaugh et.al (2006), Bhojraj dan Sengupta (2003) yang menemukan bukti bahwa komposisi dewan komisaris independen yang besar secara signifikan akan membuat peringkat obligasi menjadi tinggi. Namun penelitian ini konsisten dengan penelitian yang dilakukan Setyaningrum (2005) yang menemukan bukti bahwa proporsi dewan komisaris independen tidak berpengaruh terhadap peringkat obligasi.

\section{Pengaruh Komite Audit terhadap Peringkat Obligasi}

Hipotesis lima menyatakan bahwa komite audit berpengaruh positif terhadap peringkat obligasi. Hasil pengujian regresi menunjukan bahwa komite audit yang diproxi oleh jumlah dewan komite audit perusahaan mendapatkan nilai signifikansi sebesar 0,010 dan tanda negatif sebesar $-0,155$. Penelitian ini 
sejalan dengan penelitian yang dilakukan oleh Indoyama Nasarud (2010) yang menemukan bahwa adanya hubungan positif bahwa komite audit berpengaruh secara signifikan terhadap peringkat obligasi.

Dapat disimpulkan bahwa semakin tinggi atau semakin banyak komite audit, maka akan menyebabkan peringkat obligasi semakin baik. Di dalam teori agensi disebutkan bahwa adanya masalah agensi adalah ketika manajer mempunyai informasi pribadi tetapi tidak ingin ditransparankan atau terjadinya asimetri infromasi. Maka untuk mengatasi hal ini diperlukan adanya komite audit. Komite audit mempunyai wewenang dalam menilai pengendalian internal dan pelaporan eksternal.

Komite audit ini akan meningkatkan kualitas keseluruhan dari proses pelaporan keuangan perusahaan dan akan memastikan bahwa perusahaan menerapkan prinsip-prinsip akuntansi yang akan menghasilkan informasi keuangan yang akurat dan berkualitas maka hal ini akan berdampak pada reputasi dan akan berdampak pada peringkat obligasi perusahaan tersebut. Hasil penelitian ini konsisten dengan penelitian yang dilakukan Setyaningrum (2005) dan Rinaningsih (2008) yang menemukan bukti bahwa kualitas transparansi dan pengungkapan informasi keuangan yang diukur dengan komite audit memiliki hubungan yang positif signifikan dengan peringkat obligasi.

\section{Pengaruh Pertumbuhan Perusahaan terhadap Peringkat Obligasi}

Tingkat profitabiltas atau pertumbuhan perusahaan yang baik diharapkan akan membuat resiko ketidakmampuan membayarnya (default) semakin rendah dan semakin baik peringkat yang diberikan terhadap perusahaan tersebut. Hasil hipotesa enam menyatakan bahwa profitabilitas perusahaan yang diproxi oleh Return On Asset berpengaruh positif terhadap peringkat obligasi. Hasil pengujian regresi memiliki nilai koefisien 5,522 dengan tingkat signifikansi sebesar 0,003 dan nilai statistik wald sebesar 8,536. Nilai signifikansi lebih kecil dari 0,05 maka H6 diterima. Hasil penelitian terhadap variabel pertumbuhan berpengaruh positif signifikan terhadap peringkat obligasi perusahaan. Artinya semakin tinggi tingkat profitabilitas perusahaan 
maka akan semaikn resiko ketidakmampuan membayar dan diharapkan peringkat yang akan diberikan kepada perusahaan tersebut semakin baik.

Hasil penelitian ini tidak konsisten dengan penelitian yang dilakukan oleh Almilia dan Devi (2007) yang menemukan bahwa ROA tidak berpengaruh terhadap prediksi peringkat obligasi. Namun hasil penelitian ini konsisten dengan penelitian yang dilakukan Manurung (2007) yang membuktukan bahwa ROA berpengaruh positif terhadap peringkat obligasi.n yang positif antara pertumbuhan perusahaan terhadap peringkat obligasi.

\section{Pengaruh Rasio Leverage terhadap Peringkat Obligasi}

Hipotesis tujuh menyatakan bahwa pengaruh rasio leverage terhadap peringkat obligasi adalah positif. Rasio leverage adalah rasio keuangan yang menunjukan proporsi penggunaan utang membiayai investasi terhadap modal (Myers,2007:86). Pada penelitian ini rasio leverage yang di proxi oleh Debt to Equity Ratio mempunyai nilai signifikansi sebesar 0,022 dan tanda koefisien adalah positif 1,638 dan wald sebesar 5,254.

Nilai signifikansi pada penelitian ini sebesar 0,022 merupakan nilai yang mendukung hipotesa bahwa pengaruh rasio leverage terhadap peringkat obligasi adalah positif. Hal ini dapat disimpulkan bahwa H7 diterima. Artinya setiap kenaikan satu Debt to Equity Ratio akan membuat rating obligais naik sebesar 0,022. Dilihat dari tanda koefisiennya pada proxy rasio leverage mempunyai tanda positif. Hal ini kemungkinan menandakan semakin tingginya rasio leverage maka semakin baik peringkat yang diberikan (Hardwic,dkk 1998 dalam Manurung, 2009:11).

Rendahnya leverage pada suatu perusahaan mengindikasikan bahwa proporsi penggunaan utang untuk membiayai investasi terhadap modal yang dimiliki memiliki kemampuan yang baik. Hal ini mengindikasikan perusahaan dengan tingkat leverage yang tinggi cenderung memiliki kemampuan yang rendah dalam memenuhi kewajibannya. Hasil penelitian ini sejalan dengan penelitian yang dilakukan oleh Manurung (2007) yang menemukan bahwa rasio levergae berpengaruh positif terhadap peringkat obligasi.

\section{Pengaruh Rasio Produktivitas terhadap Peringkat Obligasi}


Hipotesis delapan mengindikasikan bahwa rasio produktivitas berpengaruh positif terhadap peringkat obligasi. Hal ini dibuktikan dengan hasil penelitian yang di proxi oleh Sales to Current Assets mempunyai nilai signifikansi 0,261 dan tanda koefisien positif 1,05 dengan wald sebesar 0,261. Dengan nilai signifikansi sebesar 0,261 maka dapat dismpulkan bahwa rasio produktivitas tidak berpengaruh terhadap peringkat obligasi. Tetapi dilihat dari tanda koefisiennya sama dengan hipotesis yanitu positif. Dapat disimpulkan bahwa H8 ditolak.

Hasil penelitian ini tidak mendukung penelitian yang dilakukan Amrullah (2007) yang menenmukan bahwa rasio produktivitas berpengaruh terhadap peringkat obligasi, namun koefisien yang diharapkan sama dengan penelitian Margaretha dan Popy Nurmayanti (2009) yaitu positif. Proxi rasio produktivitas tidak bepengaruh kemungkinan dikarenakan masih kurangnya perusahaan yang dijadikan obyek pada penelitian memanfaatkan aktiva yang dimilikinya. Hal itu berpengaruh pada rasio yang dihasilkan dan juga pada kinerja perusahaan. Tetapi dilihat dari tanda positif yang ada, bahwa setiap kenaikan Sales to Current Assets maka hal tersebut akan membuat kenaikan peringkat obligasi sebesar 0,26 satuan.

\section{Pengaruh Rasio Solvabilitas Terhadap Peringkat Obligasi}

Rasio Solvabilitas suatu perusahaan menunjukan kemampuan perusahaan untuk memenuhi segala kewajiban finansialnya yang ada pada saat perusahaan tersebut dilikuidasi. Dengan demikian solvabilitas adalah kemampuan suatu perusahaan membayar semua kewajiban atau utangutangnya baik jangka panjang ataupun jangka pendek. Penelitian ini sejalan dengan penelitian yang dilakukan Amrullah (2007) yang menemukan bahwa rasio solvabilitas berpengaruh positif terhadap peringkat obligasi. Berpengaruh positif hal ini dikarenakan perusahaan mampu dengan baik membayar semua kewajiban jangka panjangnya. Hal ini tentunya berpengaruh terhadap peringkat obligasi. Karena kewajiban jangka panjang termasuk pembiayaan obligasi. Jadi semakin tinggi rasio solvabilitas, maka semakin baik peringkat obligasinya. Dapat disimpulkan bahwa h9 diterima. 


\section{Pengaruh Rasio Likuiditas terhadap Peringkat Obligasi}

Hipotesis sepuluh adalah rasio likuiditas berpengaruh negatif terhadap peringkat obligasi. Hal ini dibuktikan dengan hasil signifikansi sebesar 0,018 dengan tanda koefisien negatif 2,265 . Artinya setiap penurunan satu current ratio akan membuat rating turun sebesar 2,265. Hasil penelitian ini sama dengan penelitian yang dilakukan Manurung (2009) yang menemukan bahwa rasio likuiditas yang di proxi oleh current ratio mempunyai hubungan yang negatif.

Rasio likuiditas menunjukan kemampuan perusahaan untuk membayar finansial jangka pendek tepat pada waktunya. Semakin tinggi rasio likuiditas pada perusahaan tersebut maka semakin baik peringkat obligasinya. Hal ini mengindkasikan bahwa perusahaan dapat membayar kewajiban jangka pendek dengan tepat sehingga membuat kinerja keuangan pada perusahaan baik dan dapat dikatakan sehat.Penelitian ini tidak mendukung penelitian yang dilakukan Margareta (2009) dimana hasil dari penelitian yang dilakukan menyebutkan bahwa rasio likuiditas tidak berpengaruh terhadap peringkat obligasi.

\section{Pengaruh Rasio Profitabilitas terhadap Peringkat Obligasi}

Rasio profitabilitas adalah rasio yang menunjukan kemampuan perusahaan dalam menghasilkan keuntungan. Proxi yang digunakan dalam mengukur rasio profitabilitas adalah Net Profit Margin. Hasil hipotesis sebelas adalah signifikan positif. Hasil regresi menunjukan bahwa signifikansi adalah sebesar 0,75 dan koefisien negatif. Nilai signifikansi sebesar 0,75 lebih besar dari 0,05 yang menyatakan bahwa ini berarti H11 ditolak.

Hasil penelitian ini konsisten dengan penelitian yang dilakukan oleh Almilia dan Devi (2007) yang menemukan bahwa rasio profitabilitas tidak berpengaruh terhadap peringkat obligasi. Hal ini mungkin dikarenakan bahwa rasio profitabilitas yang dilihat dari laba bersih masih kurang dalam membiayai atau mendapatkan keuntungan dari penjualan yang dilakukan perusahaan.

\section{KESIMPULAN DAN SARAN}

\section{Kesimpulan}


Berdasarkan hasil analisis penelitian diketahui bahwa Nilai Nagelkerke R Square sebesar 0,459. Hal ini menunjukan bahwa variabel independen yang dapat dijelaskan oleh variabilitas variabel independen sebesar $45,9 \%$, sedangkan $54,1 \%$ dijelaskan oleh variabel lainnya. Secara bersama-sama (simultan) kesebelas variabel indepneden dalam penelitian ini berpengaruh terhadap peringkat obligasi sedangkan secara partial menunjukkan variabel yang signifikan adalah ukuran dewan komisaris, variabel komite audit, variabel pertumbuhan perusahaan yang di proxi dengan ROA, rasio Leverage, rasio solvabilitas dan Rasio Likuiditas. Variabel tersebut berpengaruh terhadap peringkat obligasi. Sedangkan variabel yang tidak signifikan adalah variabel NPM, Sales to Asset, Kepemilikan Institusi, kepemilikan manajerial,dan jumlah Komisaris.

\section{Saran}

Saran yang dapat diberikan oleh peneliti adalah 1) Emiten sebaiknya terus memperbaiki atau meningkatkan kinerja perusahaan. Dengan meningkatnya kinerja perusahaan maka akan meningkatkan peringkat obligasinya. 2) Bagi para investor yang akan menginvestasikan dananya dalam bentuk obligasi, sebaiknya memperhatikan peringkat obligasi perusahaan. Karena peringkat obligasi menggambarkan kinerja suatu perusahaan penerbit obligasi tersebut. 3) bagi peneliti selanjutnya dapat meneliti pada sampel pada perusahaan yang lebih beragam, periode pengamatan yang lebih panjang, dan menambahkan variabel lain dalam corporate governance misalnya dengan menggunakan CGPI (Corporate Governance Perception Index) serta menggunakan alat uji Multiple Discriminant Analysis (MDA).

\section{DAFTAR RUJUKAN}

Ahmed, Mumer Chapra Habib. 2008. Corporate Governance Lembaga Keuangan Syariah. Jakarta : Bumi Aksara.

Amrullah, Karim. 2007. Kemampuan Rasio Keuangan Sebagai Alat Ukur Untuk Memprediksi Peringkat Obligasi. Skripsi. : Universitas Diponegoro.

Ashbaugh, Hollis, D. Collins, and R. Lafond, 2006. “The Effects of Corporate Governance on Firms' Credit Ratings". Diakses tanggal 22 September 2012. 
Bhojraj, S., and P. Sengupta. 2003. "Effect of Corporate Governance on Bond Rating and Yield: The Role of Institusional Investors and Outside Directors". www.ssrn.com. Diakses tanggal 21 Oktober 2012.

Forum for Corporate Governance in Indonesia (FCGI). 2001. “Peranan Dewan Komisaris dan Komite Audit Dalam Pelaksanaan Corporate Governance

Perusahaan)".www.muhariefeffendi.files.wordpress.com. Diakses tanggal 12 Maret 2012.

Harmono. 2011. Manajemen Keuangan Berbasis Balanced Scorecard Pendekatan Teori, Kasus \& Riset Bisnis. Jakarta. Bumi Aksara.

Brigham dan Houston. 2010. Dasar-Dasar Manajemen Keuangan Essentials of Financial Management. Jakarta : Salemba Empat.

Jewell, Jeff dan Miles Livingston. 1998. Split Ratings, Bond Yields and Underwriter Spreads. The Journal of Financial Research ( Summer) : 185-204.

Jewwell, Jeff, \& Miles Livingstone. 2000. The Impact of a Third Credit Rating on The Pricing of Bond. The Journal of Fixed income. December : 69-85.

Kasmir. 2008. Analisis Laporan Keuangan. Jakarta : Raja Grafindo Persada.

Riyanto, Bambang dan Kusumawati, Dwi Novi 2005. “ Corporate Governance dan Kinerja: Analisis Pengaruh Compliance Reporting dan Struktur Dewan Terhadap Kinerja". Simposium Nasional Akuntansi VIII. Solo. 15-16 September.

Linanarini,Erni. 2010. Kemampuan Rasio Keuangan dalam Memprediksi Peringkat Obligasi Perusahaan di Indonesia. Skripsi. Universitas Diponegoro.

Manurung, Addler et al. 2007. “Hubungan Rasio-rasio Keuangan dengan Rating Obligasi". www.finansialbisnis.com. Diakses tanggal 23 Oktober 2010.

Manurung,Adler Haymans. 2009. Teori Investasi : Konsep dan Empiris. STIEP Press: Jakarta.

Myers, Brealey dan Marcus. 2007. Dasar-Dasar Manajemen Keuangan Perusahaan Jilid 2. Jakarta : Erlangga.

Margaretha, Farah. 2005. Teori dan Aplikasi Manajemen Keuangan Investasi dan Sumber Dana Jangka Panjang. Jakarta : Salemba Empat.

Margaretha dan Popy Nurmayanti.2009. Faktor-Faktor yang mempengaruhi Prediksi Peringkat Obligasi ditinjau dari Faktor Akuntansi dan Non AkuntansiJurnal Bisnis \& Akuntansi.vol.11 no.3. hal.143-154.

Muslich, Mohamad. 2003.Manajemen Keuangan Moderen, Analisis, Perencanaan \& Kebijakasanaan. Jakarta : PT. Bumi Aksara. 
Natalia, Lina. 2007. Pengaruh Mekanisme Corporate Govenance terhadap Pengungkapan Intellectual Capital. Universitas Pelita Harapan Surabaya.

Almilia, Luciana Spica dan Vieka Devi. 2007. “Faktor-faktor yang Mempengaruhi Prediksi Peringkat Obligasi pada Perusahaan Manufaktur yang Terdaftar di Bursa Efek Jakarta". Proceeding Seminar Nasional Manajemen SMART. 3 November

Nasarud, Indoyama. 2010. Pengaruh Good Corporate Governance dan Pertumbuhan Perusahaan terhadap Peringkat Obligasi. Jurnal Ekonomi Universitas Islam Negeri Syarif Hidayatullah Jakarta. Vol.9 no.3 : Desember.18-35.

Prasetiyo, Adhi.2010. Pengaruh Mekanisme Corporate Governance dan Profitabilitas Perusahaan terhadap peringkat Obligasi. Skripsi: Universitas Diponegoro.

Prasetyantoko,A. 2008.Corporate Governance:Pendekatan Institusional. Jakarta : Gramedia.

Rinaningsih. 2008. "Pengaruh Praktek Corporate Governance terhadap Risiko Kredit, Yield Surat Hutang (Obligasi)". Simposium Nasional Akuntansi XI. Pontianak. 23-24 Juli

Setyaningrum, Dyah. 2005. "Pengaruh Mekanisme Corporate Governance Terhadap Peringkat Surat Utang Perusahaan di Indonesia". Jurnal Akuntansi dan Keuangan Indonesia. Vol. 2. No. 2: 73-102 .

Setyapurnama, Yudi Santara dan A.M. Vianey Norpratiwi. 2006. “Pengaruh Corporate Governance terhadap Peringkat Obligasi dan Yield Obligasi". Jurnal Akuntansi \& Bisnis. Vol. 7. No. 2, Agustus 2007: 107108.

Sutedi, Adrian. 2009. Aspek Hukum \& Obligasi \& Sukuk. Jakarta : Sinar Grafika

Tampubolon, Manahan P., 2004. Manajemen Keuangan (Financial Management) Konseptual, Problem, \& Studi Kasus.Ciawi-Bogor : Ghalia Indonesia.

Ujiyantho, Muh. Arif dan Bambang Agus Pramuka. 2007. "Mekanisme Corporate Governance, Manajemen Laba dan Kinerja Keuangan". Simposium Nasional Akuntansi X. Makassar. 26-28 Juli.

Warsono, soni dkk., 2009. Corporate Governance Concept and Model Preserving true organization welfare. Yogyakarta. Center for GCG Fakultas Ekonomi dan Bissnis UGM.

Zuhrotun dan Baridwan. 2005. "Pengaruh Pengumuman Peringkat Terhadap Kinerja Obligasi". Simposium Nasional Akuntansi VIII. Solo. 15-16 September.

Zarkasyi, Wahyudin. 2008. Good Corporate Governance pada Badan Usaha Manufaktur, Perbankan dan Jasa Keuangan Lainnya. Bandung. Alfabeta. 
www.pefindo.com

www.detikfinance 